E3S Web of Conferences 1, 41009 (2013)

DOI: $10.1051 /$ e3sconf/ 20130141009

(C) Owned by the authors, published by EDP Sciences, 2014

\title{
Intake of predatory fish in Amazonia is a driver of toxicological risk for susceptible exposure groups
}

\author{
S.S.Hacon ${ }^{1}$, D. S. Mourão ${ }^{1}$, B. Oliveira ${ }^{1}$, G..P. Silva ${ }^{1}$, M. F.Freitas ${ }^{2}$, C. Vega ${ }^{3}$, R. Gonçalves ${ }^{3}$, C.F. Mariani ${ }^{4}$, N. Gomes ${ }^{5}$, \\ A.V. Souza ${ }^{5}$, W. Bastos 5 \\ ${ }^{1}$ Oswaldo Cruz Foundation, National School of Public Health, Rio de Janeiro - Brazil <sandrahacon@gmail.com>, \\ ${ }^{2}$ Instituto Fernando Figueira -Rio de Janeiro - Brazil \\ ${ }^{3}$ Pontifícia Universidade Católica do Rio de Janeiro, \\ ${ }^{4}$ Santo Antonio Energia \\ ${ }^{5}$ Federal University of Rondonia, Department of Geochemistry
}

\begin{abstract}
High fish intake has marked the scenario of riparian communities in Amazon basin during the last three decades. Although efforts have been done by some national and international scientific groups to control mercury exposure in Brazilian Amazon, the problem persists. The return of artisan gold mining, the new hydroelectric power plants (with its reservoirs) and the expansion of the agribusiness are some of the economic activities that may contribute to the increment of mercury load in the Amazon ecosystem with direct influence in the food chain. These changes in Amazon scenario increase complexity of environmental issue and mercury may become a threat for susceptible exposure groups. This study evaluated mercury exposure scenarios for susceptible groups around the hydroelectric plant to calculate toxicological risk before damming. During the period of 2009 to 2011, about 771 children under 16 years age and 276 female in reproductive age (from 16 to 40 years old) were assessed. Besides, regular fish samples $(\mathrm{n}=1580)$ were collected for total mercury determination. The mercury concentration in fish ranged from 0.01 to $6.06 \mathrm{mg} / \mathrm{kg}$. For the current scenario the toxicological risk ranged from 3.5 to 24 for mercury for the susceptible groups. Regarding the critical scenario after 3 years flooding, the area is expected to double the risk for the same group, especially for the communities downstream, which may represent a critical situation.
\end{abstract}

Keywords: mercury, fish-eating communities, fish consumption, risk to health, Brazilian Amazon.

\section{Introduction}

Fish intake has been known to be a source of mercury that contributes to high levels of mercury concentrations in fish-eating communities. Due to current and past high mercury load in the Brazilian Amazon, the human exposure through fish consumption is a concern, especially for women in reproductive age as well children due to the impact of mercury on their neurodevelopment (Mozaffarian, 2006). The risk of elevated mercury concentrations in fish has become one of the most important issues in assessing the environmental impact of hydroelectric reservoirs (Hylander et al, 2006). However, in Brazil, few studies regarding mercury contamination have been carried out in areas of constructed reservoirs.
In Amazon region, mercury levels are of even greater concern, in this particular region when factored with the effects of a hydroelectric facility being constructed in the area, and continued gold mining in the region (Meng, 2010).

This study looks to investigate the mercury exposure scenarios for susceptible groups of the riverine communities and to estimate the toxicological risk of mercury presented by the environmental before damming.

\section{Materials and Methods}

The study area is part of occidental Brazilian Amazon in the municipality of Porto Velho, capital of 
Rondonia (coordinates $8^{\circ} 47^{\prime} 31^{\prime \prime} \mathrm{S}$ and $63^{\circ} 57^{\prime} 7^{\prime \prime} \mathrm{W}$ ). The hydroelectric plant is located in the waterfall in the Madeira River, about $6 \mathrm{~km}$ along the river, upstream from Porto Velho. The hydroelectric plant started to be built in 2008, and has an area estimated in $46 \mathrm{~km}^{2}$. The study area comprised about $200 \mathrm{~km}$ downstream and $50 \mathrm{~km}$ upstream. It was made up of 300 households with 1047 individuals from 25 communities with an age range from 1 year and 40 years old (Figure 1). The fieldwork was carried out between April of 2009 and March of 2011, before flooding the reservoir area. A cross-sectional study for assessment of the exposure for susceptible groups (children and adolescent $<16$ years and female between 16 and 40 years of age) was carried out applying a detailed interview administered questionnaire to collect socio-demographic data, medical and occupational history, anthropometric measures, life habits, and a dietary survey (including species preferences and frequency of fish consumption).

We estimated the intake and toxicological risk of mercury for the susceptible groups using the methodology of Risk Assessment from the Agency for Toxic Substances and Disease Register (ATSDR 2005) adapting the needs for the local approach. Fish specimens were collected by the ichthyofauna group from the Biology Department of Rondonia University and total mercury (THg) concentration was determined by the Biogeochemistry Laboratory at the same University. Mercury concentrations were measured in different trophic levels of fish species consumed by riverine communities. The determination of $\mathrm{THg}$ in fish was performed by cold vapor atomic absorption spectrophotometer coupled with cold vapor generation FIMS-400®, Perkin Elmer (Bastos et al 1998). Analytical control and accuracy were assured by the use of internal standards prepared in the Biogeochemistry Laboratory of Rondonia University and reference certified samples (Dogfish Muscle-DORM-2) National Research Council Canada. The amount of fish consumed was obtained applying the 24-72 hour dietary recall (Buzzard, et al, 1996). The body weight for all groups was obtained with anthropometric measures.

Model was used to estimate the dose and risk by the general equation for risk assessment. The mean and P95 doses of $\mathrm{THg}$ were calculated according to age groups and gender. Two scenarios were considered, upstream and downstream. The general equation for potential dose was

$$
\mathrm{I}=\mathrm{C}_{\mathrm{Hg}} \times \frac{\mathrm{IF} \times \mathrm{FA} \times \mathrm{ET} \times \mathrm{EF} \times \mathrm{ED}}{\mathrm{BW}} \times \frac{1}{\mathrm{AT}}
$$

Where:

$$
\mathrm{I}=\text { Potential Dose }(\mu \mathrm{g} / \mathrm{kg} \text {.day })
$$

\author{
$\mathrm{CHg}=$ Concentration $\mathrm{THg}(\mathrm{mg} / \mathrm{kg})$ \\ $\mathrm{IF}=$ Ingestion of fish ( $\mathrm{mg} /$ day) \\ $\mathrm{FA}=$ Factor of Absorption \\ $\mathrm{ET}=$ Exposure Time (hrs/day) \\ $\mathrm{EF}=$ Exposure Frequency (days/year) \\ BW. Body weight
}

The US.EPA defined $0.1 \mu \mathrm{g} / \mathrm{kg} / \mathrm{d}$ as a Reference Dose for methylmercury of a daily exposure to the human population. This dose is a reference to evaluate the potential effects including sensitive subgroups.

\section{Results and Discussion}

During the period of 2009 to 2011 about 771 children under 16 years age and 276 female in reproductive age (from 16 to 40 years old) were interviewed and taken anthropometric measure. Participants' age varied between 1 and 40 years old with a mean of 9 years for children and 29 for female $>16$ years of age. The main characteristic of the participants are lack of sanitation, no water supply system, water is retrieved from the river or well water, very irregular and low income, low education level, precarious health services, high prevalence of parasitizes, malaria and usual respiratory diseases.

During the same period, 1580 fish specimens were analyzed for $\mathrm{THg}$. The concentrations by trophic categories are presented in the Table 1 . The fish captured upstream in relation to the hydroelectric plant showed a higher $\mathrm{THg}$ concentration in relation to fish from downstream $(\mathrm{P}<0.05)$. As usual, predatory fish presented the highest $\mathrm{THg}$ concentrations ranging from 0.02-6.06 $\mathrm{mg} / \mathrm{kg}$ with a mean of $0.83 \mathrm{mg} / \mathrm{kg} \pm 0.85$.

For downstream scenario the group of children under 16 years of age, the fish consumption ranged from $20 \mathrm{~g}$ to $138 \mathrm{~g}$ daily. For the female above 16 to 40 years the fish consumption ranged from $48 \mathrm{~g}$ to $140 \mathrm{~g}$. The perspective of the critical scenario the consumption maintained stable. However the $\mathrm{THg}$ concentration in fish may increase about 2-3 times.

For upstream scenario the group of children under 16 years of age, the fish consumption ranged from $70 \mathrm{~g}$ to $150 \mathrm{~g}$ daily. For the female above 16 to 40 years the fish consumption ranged from $60 \mathrm{~g}$ to $160 \mathrm{~g}$. The perspective of the critical scenario, should maintain the rate of fish consumption, also the $\mathrm{THg}$ concentration in fish may increase about 3 times in comparison with the current scenario that should be modified due to changes of diet habits. The upstream and downstream scenarios showed results statistically significant $(\mathrm{P}<0.05)$. 


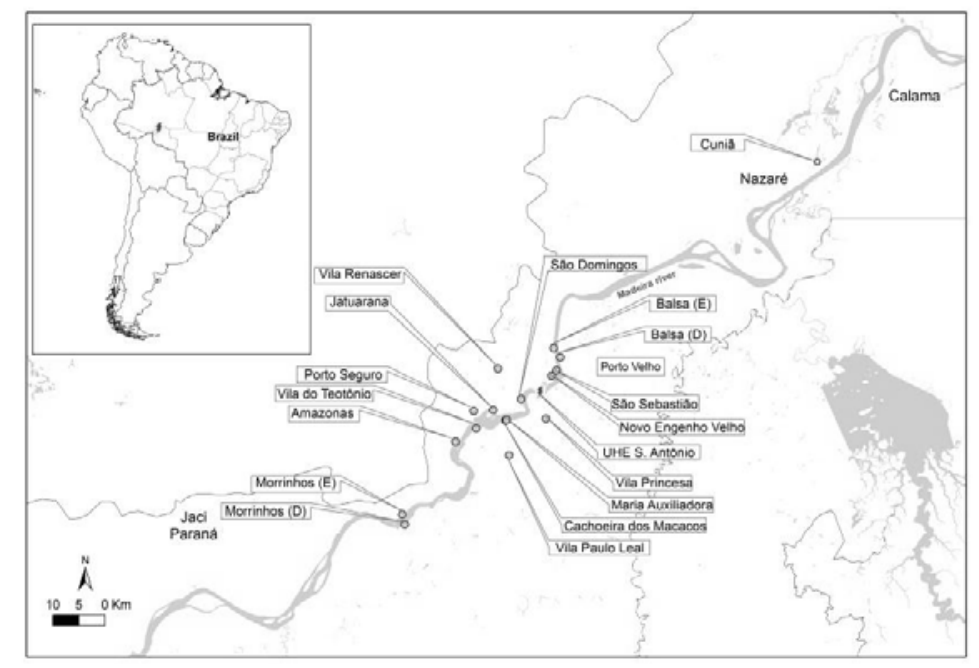

Fig. 1. Madeira river and the area studied and the indication of the communities and the fish collected

Table 1. Descriptive Statistic for $\mathrm{Hg}(\mathrm{mg} / \mathrm{kg})$ in different fish trophic levels consumed by the riverrine communities in Madeira River for the period of 2009-2011.

\begin{tabular}{ll|cccc}
\hline $\begin{array}{c}\text { Reservoir } \\
\text { Hidroeletric plant }\end{array}$ & Trophic Level & N & Mean (SD) & Minimum & Maximum \\
\hline Downstream & Carnivorous & 220 & $0,7(0.57)$ & 0.02 & 4.14 \\
& Detritivorous & 352 & $0.19(0.19)$ & 0.01 & 1.11 \\
& Herbivorous & 84 & $0.11(0.14)$ & 0.02 & 0.8 \\
& Insectivorous & 9 & $0.34(0.18)$ & 0.16 & 0.7 \\
& Omnivorous & 230 & $0.28(0.24)$ & 0.03 & 1.42 \\
& Total & 895 & $0.32(0.39)$ & 0.01 & 4.14 \\
& Carnivorous & 252 & $0,97(1.01)$ & 0.02 & 6.06 \\
& Detritivorous & 165 & $0.10(0.13)$ & 0.01 & 0.86 \\
& Herbivorous & 16 & $0.05(0.05)$ & 0.01 & 0.19 \\
& Insectivorous & 46 & $0.30(0.25)$ & 0.04 & 0.93 \\
& Omnivorous & 225 & $0.19(0.19)$ & 0.01 & 1.44 \\
& Total & 704 & $0.45(0.73)$ & 0.01 & 6.06 \\
\hline
\end{tabular}

Table 2. Upstream and downstream exposure scenarios in Madeira river in relation to the Hydroelectric plant, regarding a mean dose $(\mathrm{mg} / \mathrm{kg} / \mathrm{d})$ and a critical exposure P $95 \%(95 \% \mathrm{CI})$ for the susceptible groups.

\begin{tabular}{cl|ccccc}
\hline $\begin{array}{c}\text { Reservoir } \\
\text { Hidroeletric plant }\end{array}$ & \multicolumn{1}{c}{ Group age } & N & Mean & P95 & Mean & P95 \\
\hline \multirow{3}{*}{ Upstream } & Male <16 year old & 141 & $2.4(0.24-9.4)$ & $5.1(1.18-16)$ & $24(2.4-94)$ & $51(11.8-160)$ \\
& Female < 16 year old & 154 & $1.04(0.18-7.7)$ & $4.3(1.1-19.3)$ & $10.4(1.8-77)$ & $43(11-193)$ \\
& Woman 16 to 40 & 114 & $0.75(0.14-4.1)$ & $3.3(1.03-8.8)$ & $7.5(1.4-41)$ & $33(10.3-88)$ \\
\hline \multirow{4}{*}{ Downstream } & Male <16 year old & 230 & $1.22(0.22-6.9)$ & $5.1(1.18-16)$ & $12.2(2.2-69)$ & $51(11.8-160)$ \\
& Female < 16 year old & 246 & $0.35(0.4-3.0)$ & $3.2(0.72-8.7)$ & $3.5(4-30)$ & $32(7.2-87)$ \\
& Woman 16 to 40 & 162 & $0.64(0.13-2.7)$ & $2.1(0.64-4.6)$ & $6.4(1.3-27)$ & $21(6.4-46)$ \\
\hline
\end{tabular}




\section{Conclusion}

This study allows scientific communities, decision makers and the general society to have more knowledge about environmental impacts of mercury before flooding and after filling the reservoir, especially the magnitude of $\mathrm{Hg}$ in fish which will be reflected in human $\mathrm{Hg}$ load.

Regarding the critical scenario after 3 years, flooding the area is expected to increase the risk for $\mathrm{Hg}$ exposure especially for the communities downstream, which may represent a critical situation. One has to regard that the government plan to build small hydroelectric plants in Amazon basin needs more attention to health risk due to mercury exposure for the riverine population, which their subsistence depend on fish for their main source of protein.

\section{Acknowledgements}

The authors thank the financial supports providing from Santo Antonio Energy, FIOCRUZ-INOVA ENSP and CNPq ( proc. 478085/2010-9).

\section{References}

ATSDR ToxProfiles . Agency for Toxic Substances and Disease Registry, Department of Health and Human Services. Atlanta, GA.2005.

Bastos WR, Malm O,Pfeiffer WC.Establishment and analytical quality control of baboratories for $\mathrm{Hg}$ determination in biological and geological samples in Amazon, Brasil. Ciencia Cultura 1998,50.,255-260

Buzzard, I. M., Faucett, C. L., Jeffery, R. W., McBane, L., McGovern, P., Baxter, J. S., Shapiro, A. C., Blackburn, G. L., Chlebowski, R. T., Elashoff, R. M., and Wynder, E. L. (1996). Monitoring dietary change in a low-fat diet intervention study: advantages of using 24-hour dietary recalls vs food records. J. Am. Diet. Assoc. 96, 574-579.

Hylander L D, Grohn J, Tropp M, Vikstrom A, Wolpher H, Fish mercury in Lago Manso, a new hydroelectric reservoir in tropical Brazil.2006,Journal of Environmental Management 2006,81:155-166.

Meng B, Feng XB, Chen CX, Qiu GL, Sommar J, Guo YN, Liang P, Wan Q. Influence of eutrophication on the distribution of total mercury and methylmercury in hydroelectric reservoirs. J Environ Qual. 2010 Sep-Oct;39(5):1624-35. PubMed PMID: 21043268. 